\title{
Effective school cooperative-mart queuing system
}

\author{
Ahmad Ridhuan Hamdan, Ruzana Ishak, Mohd Fais Usop* \\ Razak School of Engineering and Advanced Technology, University Teknologi Malaysia, 54100 Kuala Lumpur, Malaysia \\ *Corresponding author : ruzana.kl@utm.my
}

\section{Article history}

Received 24 October 2017

Accepted 8 November 2017

\begin{abstract}
Queuing Theory is a branch of knowledge in operation research that concerning the analysis of queues when a customer arrives at a service centre and shall queue in a line to get some service. The theory pays attention to how organizations can serve a large number of customers who demand a quality services and a queue of customers waiting to be served. Eventually, the store owners have to attend to large numbers of customers at a time have attempted to measure and manage queues to reduce the customer procession time. Besides, to increase sales and profit, productivity and operation efficiency, satisfaction levels and customer loyalty in using the service provided. In line to the situation, this study is to determine the effectiveness of the waiting line using Queuing Theory at cooperative-mart. Until today, no research conducted about school cooperatives-mart to observe and solve the massive inflow of customers at lines at a given time especially during lunch hour. The purposes of this study are to determine the customer congestion at the payment counter and to propose the effective queuing system at Cooperativemart. Waiting and services times of customers at cooperative-mart is studied in three times period that to be considered as peak hours in two types of counter which are for male and female. Data collection was observed by using queuing theory and the $M / M / 1 / \infty / \infty$ queuing model has been implemented. The results show that for optimum service level, the counter must be changed from one to two counters each side. The summary and finding of the study shall be used as guideline for the management of cooperative-mart in deciding improvement of its operation.
\end{abstract}

Keywords: Queuing theory, queuing system, queue system performance parameter

\section{INTRODUCTION}

Cooperative is an organisation lead by a group of people in society, which collectively accumulate a capital to run activities and providing services or products for the members. Despite being run as a business oriented organisation, however its motives are not necessarily for profit, merely to prioritize its members' welfare. The school cooperative is a Statutory Corporation which registered under Act 502, Cooperative Act 1993, overseen by the Jabatan Pembangunan Koperasi (JPK). A basis of setting up a cooperative is to allow students to learning about managing their own financial, be independent and to live in a society, upon a democratic principle. According to RINGKASAN PERANGKAAN AM KOPERASI SEKOLAH MENGIKUT NEGERI 2016, until June 2016, there were reported to be a total of 2361 school cooperative with members amounting to 2,078,224 and shares worth of RM 298,554,938 (2016).

According to Norazlan et al. (2010) cooperative users in Malaysia that run stores, cooperatives experienced quite numbers of difficulties. Among the main problems are, competition by the private sector, members that are inexperienced in store management, difficulties in recruiting a qualified staff, limited products selection available in the store, meagre fixed capital and the high overall managing costs (operation costs, fixed costs, variable costs and many more), high prices of most stock purchases and most customers who were buying at the cooperative were not actually members of the cooperative.
The main problem among school cooperatives are the numbers of customers in the cooperative at one time especially during lunch hour. The situation is worse when the school's policy does not allow students to go to the canteen during lunch hour. Only teachers, staff and guests are allowed to dine at the canteen. Additionally, the small area of the cooperative and the dense pack of students can be hypothesised a number of problems arise such as thievery, damage facilities and long waiting times which will worsen if pre-emptive measures are not taken to overcome this problem.

\section{LITERATURE REVIEW}

Total checkout service time is defined as the time a consumer is prepared to be served and joins the waiting line to the time a customer is being served and obtains receipts for payment of items bought. A wait for service is said to be the time a customer is prepared to receive service until the time the service starts (Taylor, 1994). A number of these studies, most notably conducted by the likes of (Weisselburg et al., 1969; Crahill et al., 1977; Foote, 1976; Jones et al., 1980), have tried to analyse ways to reduce waiting time in queuing lines by observing the perception of customers towards different wait times in waiting lines and how its influences their behaviour towards the store they shop. These researches have further supported that time plays an important role in consumer behaviour. As such, the focus of their 
study was to minimize the time that customers spent waiting in a queue.

Many studies in the past also have been conducted to solve waiting in checkout lines. (Friedman et al., 1997) have advised that the paradigm of waiting should be used "waiting line segmentation". This waiting line technique can exist by creating a VVIP counter like the ones practiced at 5 star hotels, movie theatres or theme park. Barnett, A.I., Saponaro, A. (1985) discussed the possibility that staying in waiting lines could be correlated with good sensations and comparable perhaps with the feelings of social acceptance. This is because in a queue, a person may indirectly make new friends and sociability as one is surrounded by other humans, or the enthusiasm felt at being a member of a crowd at a sports event. Smith (1999) stated that managers are prepared to allow some waiting if great sums of service cost are saved balances the waiting. Service costs are directly proportionate to the level of service of a firm to its consumers. Managers in some centers of servicing can diversify their volume by having standby staff to open up extra checkout lines or devices that can be designated to certain service stations to avoid or reduce excessively long lines. Vinta (1999) has pointed out that international grocery store chains have used queuing models in choosing the highest number of counters that are needed to be opened during rush hours in hopes that each customer must only wait for at least 15 minutes before making payments at the counter. Sahu (2014) proposed an $\mathrm{M} / \mathrm{M} / 1: \mathrm{FCFS} / \infty / \infty$ for queuing management system in a bank with a single channel. The illustrated model in the bank for customers on a level with service was the single-channel queuing model with poisson arrival and exponential service time (M/M/1).

As a conclusion from the review of literature in this research, it is indicate that both time and convenience play important roles that managers should oversee when choosing and applying the best checkout systems for their establishment. Today, retail industrial managers are applying various techniques and learning of new checkout systems to aid them in improving the current process of customer checkout.

\section{METHODOLOGY}

\section{Research Procedure}

A quantitative research approach was used in this study. Ten assistants have been appointed in collecting primary data which included the daily record of waiting time for five days at two payment counters as known as Girls Payment Counter (GPS) and Boys Payment Counter (BPS). In collecting the data, each research assistants were equipped with a digital watch and a queuing form was handed over to the customers once they started to queue and make payment at a counter. The customer will hold the queuing form until they leave the cooperative-mart with the information regarding the waiting time. The process mentioned above will be repeated to another customer. Respondent for this study were students throughout the three lunch break which are at $10.00 \mathrm{am}$ to $10.30 \mathrm{am}, 2.30 \mathrm{p} . \mathrm{m}$ to $3.00 \mathrm{p} . \mathrm{m}$ and after school evening activities at $4.00 \mathrm{pm}$ to $4.30 \mathrm{pm}$ for comparison. Queuing systems method was used to analyse the data.

This serving counters was found following the $\mathrm{M} / \mathrm{M} / 1$ queuing model. The data collected from this study will be compiled and summarized into Microsoft Excel spreadsheet. Then data will be validated by applying an online calculator at http://www.supositorio.com/rcalc/rcalclite.htm which made available to be used.

\section{M/M/1 Queuing Model}

In the case of school cooperative-mart, the queuing system comprised of a single waiting line and a single server. There are separate counters for male customer(boys) and female customer(girls) as the school cooperative management would like to prevent the mingle of both genders during queuing. By definition, these payment counters are single waiting line and a single server. The Figure 1 illustrated the definition.

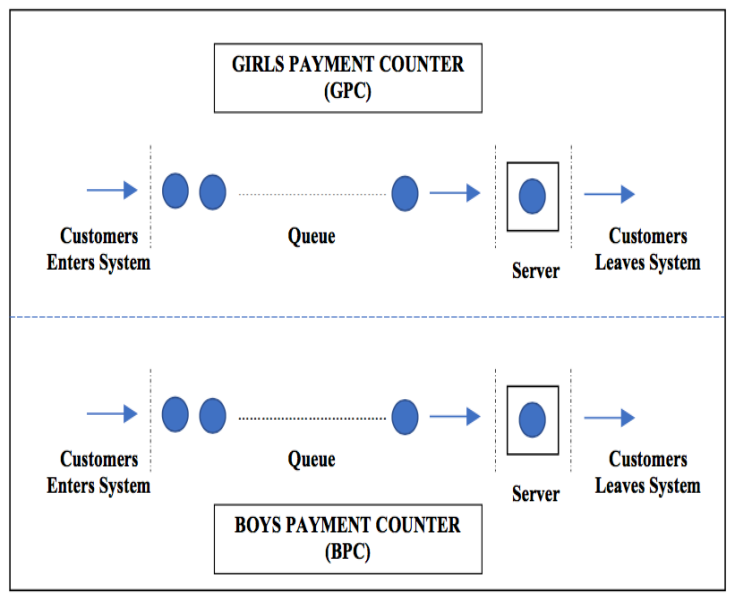

Figure 1 Single stage queuing model with single-queue and singleserver.

Therefore, for Single-Queue and Single-Server model, the assumptions applied in this study are as follows:

i. Arrivals of customers at cooperative-mart are following a Poisson process.

ii. Inter-arrival times of a Poisson process are exponentially distributed.

iii. Services time at each payment counter are exponentially distributed.

iv. Identical service facilities including size of counter and number of staff in-charge at both counters.

v. None of the customers leaves the queue without being served.

vi. Each queue has no limitation of customers queue in the line. Therefore, infinite number of customers in queuing system.

vii. Customers arrival on the queue are served on a First Come First Serve (FCFS) queuing discipline basis.

viii. No balking, reneging or jockeying during waiting in the line for service at BPC and GPC

In this assumption, customer who arrives from a flow that was different equally treated by putting them into the queues with strict respect to their arriving order. Those who were already on the queue were served in the same order as they were entered. This means that the earliest customer that enters the queue will be the first one that exits. All customers who arrive and enter into the queuing system will approximately receive service according to the equally distributed service time.

\section{Queuing Theory Equations}

To analyse using $\mathrm{M} / \mathrm{M} / 1$ queuing model, the following variables will be investigated:

$\lambda=$ Mean arrival rate (number of arrivals per unit of time)

$\mu=$ Mean service rate per server

$\rho=$ Utilization Factor

$P(0) \quad=$ Probability of zero customers in the system

Ls = Average number of units (customers) in the system

$L q=$ Average number of customers in the queue (waiting to be served)

$W_{S}=$ Average waiting time in the system

$W q=$ Average waiting time in the queue 
Table 1 Single and multiple-channel queuing model equation.

\begin{tabular}{|c|c|c|}
\hline & $\begin{array}{l}\text { Single Line-Single } \\
\text { Server (M/M/1) }\end{array}$ & $\begin{array}{c}\text { Single Line-Multiple Server } \\
\text { (M/M/C) }\end{array}$ \\
\hline$\rho$ & $\rho=\frac{\lambda}{\mu}$ & $\rho=\frac{\lambda}{s \mu}$ \\
\hline$P(0)$ & $\mathrm{Po}=1-\frac{\lambda}{\mu}$ & $\mathrm{Po}=\frac{1}{\sum_{n=0}^{S-1} \frac{(\rho)^{n}}{n !}+\frac{(\rho)^{S}}{S !\left(1-\frac{\rho}{S}\right)}}$ \\
\hline$L q$ & $L q=\frac{\lambda^{2}}{\mu(\mu-\lambda)}$ & $L_{q}=\frac{(\rho)^{S+1}}{S ! S\left(1-\frac{\rho}{S}\right)^{2}} P_{0}$ \\
\hline$L s$ & $L s=\frac{\rho}{1-\rho}=\frac{\lambda}{\mu-\lambda}$ & $L_{s}=\left[\frac{(\rho)^{s}}{\mu S ! S\left(1-\frac{\rho}{S}\right)^{2}} P_{0}+\frac{1}{\mu}\right] \lambda$ \\
\hline$W q$ & $W q=\frac{\lambda}{\mu(\mu-\lambda)}$ & $W_{q}=\frac{(\rho)^{S}}{\mu S ! S\left(1-\frac{\rho}{S}\right)^{2}} P_{0}$ \\
\hline$W s$ & $W s=\frac{1}{\mu-\lambda}$ & $W s=\frac{(\rho)^{S}}{\mu S ! S\left(1-\frac{\rho}{S}\right)^{2}} P_{0}+\frac{1}{\mu}$ \\
\hline
\end{tabular}

By using the Excel Spreadsheet, the average of the arrivals rate $(\lambda)$ and the average of service rate $(\mu)$ will be determined for each counter. From this arrivals and service rate value, queuing performance parameter can be measured using the formula listed in Table 1. All of this formula are measured and calculate manually if we want to find queue performance parameter. However in this study, queue performance parameter will be calculated by Queuing Calculator to measure $\mathrm{M} / \mathrm{M} / 1$ and $\mathrm{M} / \mathrm{M} / \mathrm{C}$. It is worthy to note that the formulas can be applied only if $\mu$ is greater than $\lambda$. In other words, they can be applied only if $\frac{\lambda}{\mu}<1$ or when the rate of arrivals is less than the rate of departures. Failing to meet this condition leads to a growing of the waiting line, because the service capacity is insufficient.

\section{RESULTS AND DISCUSSION}

The study reflects a minimum ratio of participants between boys and girls distributed daily. The finding shows congestion in the payment counters happening on every school day, from Monday to Friday. Started on the operating hour at 10.00 a.m. to $10.30 \mathrm{am}$, students will scramble in to buy packed of food after they are famished from the long sessions of teaching learning since early morning. A high percentage of group arrival patterns are $78 \%$ imposed direct increase congestion volume. The average number of student customers by day is illustrated in Figure 2.

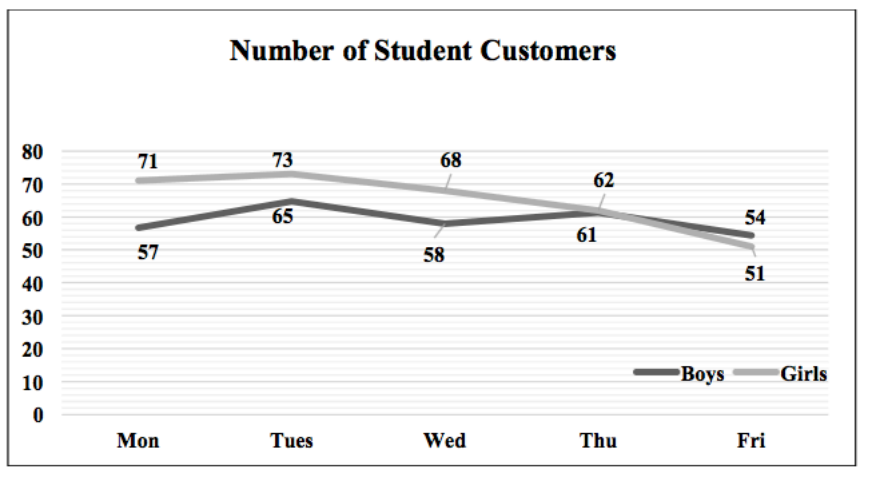

Figure 2 Average number of student customers by day.

The data collection identified that there are two important queuing theory performance parameters. The arrival and service rate for both counters. This parameter will be an input of the Queuing Theory formula analysis. Nevertheless, analysis continued with Queuing Theory Calculator to get another data of performance parameter. The $\mathrm{M} / \mathrm{M} / 1$ Queuing Model is applied to the data collected from the study for both BPC and GPC. Queuing Theory performance parameters of single server were derived as shown in Table 2. In Table 3 and 4 , shows the comparison between single and multi-server

Table 2 Single-server statistical result for each counter.

\begin{tabular}{|c|c|c|}
\hline $\begin{array}{c}\text { Performance } \\
\text { Parameter }\end{array}$ & $\begin{array}{c}\text { Boys Payment } \\
\text { Counter ( BPC })\end{array}$ & $\begin{array}{c}\text { Girls Payment } \\
\text { Counter ( GPC })\end{array}$ \\
\hline $\begin{array}{c}\text { Number of Servers } \\
(\mathrm{C})\end{array}$ & 1 & 1 \\
\hline $\begin{array}{c}\text { Arrival rate }(\lambda) \\
\text { Serving rate }(\mu)\end{array}$ & $\begin{array}{c}112 \text { customer per } \\
\text { hour }\end{array}$ & $\begin{array}{c}112 \text { customer per } \\
\text { hour }\end{array}$ \\
\hline $\begin{array}{c}\text { Overall system } \\
\text { per hour }\end{array}$ & $80.00 \%$ & $\begin{array}{c}\text { customer per } \\
\text { hour }\end{array}$ \\
\hline $\begin{array}{c}\text { Probability of zero }(\rho) \\
\text { customers in the } \\
\text { system }\left(P_{0}\right)\end{array}$ & 0.2 & $77.78 \%$ \\
\hline $\begin{array}{c}\text { Average number of } \\
\text { customers in the } \\
\text { system }(\mathrm{Ls})\end{array}$ & 4 customer & 3.5 customer \\
\hline $\begin{array}{c}\text { Average number of } \\
\text { customers in the } \\
\text { queue }(\mathrm{Lq})\end{array}$ & 3.2 customer & 2.722 customer \\
\hline $\begin{array}{c}\text { Average time } \\
\text { customer spends in } \\
\text { the system }(\mathrm{Ws})\end{array}$ & 0.0357 hours & 0.0313 hours \\
\hline $\begin{array}{c}\text { Average time a } \\
\text { customer spend in } \\
\text { queue }(\mathrm{Wq})\end{array}$ & 0.0286 hours & 0.0243 hours \\
\hline \multicolumn{2}{|c|}{} & \\
\hline
\end{tabular}

According to Table 1, overall system utilization is $80 \%$ at both counters. This shows the busy factor of the serving system measures the efficiency of the queuing system. A lower utilization factor is preferred for more efficiency in the waiting line. Hence, this performance parameter for both counters shows that there are many aspects can be done to manage its queues and to improve customer satisfaction. 
Table 3 Single-server and multi-server comparison for BPC.

\begin{tabular}{|c|c|c|c|c|}
\hline PARAMETERS & $\mathbf{M} / \mathbf{M} / \mathbf{1}$ & $\mathbf{M} / \mathbf{M} / \mathbf{2}$ & $\mathbf{M} / \mathbf{M} / \mathbf{3}$ & $\mathbf{M} / \mathbf{M} / \mathbf{4}$ \\
\hline $\mathrm{I}$ & 112 & 112 & 112 & 112 \\
\hline$\mu$ & 140 & 140 & 140 & 140 \\
\hline$r$ & $80.00 \%$ & $40.00 \%$ & $26.67 \%$ & $20.00 \%$ \\
\hline$P(0)$ & 0.2 & 0.6 & 0.7373 & 0.8 \\
\hline$L s$ & 4 & 0.952 & 0.8189 & 0.8024 \\
\hline$L q$ & 3.2 & 0.152 & 0.0189 & 0.0024 \\
\hline$W s$ & 0.0357 & 0.0085 & 0.0073 & 0.0072 \\
\hline$W q$ & 0.0286 & 0.0014 & 0.0002 & 0 \\
\hline
\end{tabular}

Table 4 Single-server and multi-server comparison for GPC.

\begin{tabular}{|c|c|c|c|c|}
\hline PARAMETERS & $\mathbf{M} / \mathbf{M} / \mathbf{M}$ & $\mathbf{M} / \mathbf{M}$ & $\mathbf{M} / \mathbf{M} / \mathbf{3}$ & $\mathbf{M} / \mathbf{M} / \mathbf{4}$ \\
\hline $\mathrm{I}$ & 112 & 112 & 112 & 112 \\
\hline$\mu$ & 144 & 140 & 140 & 140 \\
\hline$r$ & $77.78 \%$ & $38.89 \%$ & $25.93 \%$ & $19.44 \%$ \\
\hline$P(0)$ & 0.222 & 0.611 & 0.7407 & 0.8056 \\
\hline$L s$ & 3.5 & 0.9164 & 0.7947 & 0.7799 \\
\hline$L q$ & 2.722 & 0.1386 & 0.0169 & 0.0021 \\
\hline$W s$ & 0.0313 & 0.0082 & 0.0071 & 0.007 \\
\hline$W q$ & 0.0243 & 0.0012 & 0.0002 & 0 \\
\hline
\end{tabular}

In Table 3 and 4, it was seen that the performance parameter for both of counter are almost identical. Results show that overall system utilization $(\rho)$, is significantly improved up to $50 \%$ reduction by adding new additional serving counter. The value of the utilization factor is not the only one to decrease. Almost all four performances parameter for the queuing system above had decreased almost half or $50 \%$ better when number of server increase. Even though increasing number of servers show that the waiting line becoming more efficient at both counters, however the costs of management to hire more staff and the limited space of the cooperative-mart should be considered. Hence, it is not suitable to increase the servers from one to four servers. Based on the comparison table above, the optimum server that is advised needs to be increased at the BPC and GPC to overcome the problems of overcrowding is only two servers per counter.

\section{CONCLUSION}

This paper presents the cause of waiting line congestion at school cooperative at MRSM Alor Gajah by applying the Queuing Theory method. The queuing performance parameters were applied and analysed. Result shows by adding a new service counter for both queues would significantly reduce the waiting line and make it more adequate. The outcome of this research could be beneficial to school cooperative management in quantifying the waiting line efficiency level. It also will become a guideline in deciding any improvement plan after considering the causes and effects to all relevant stakeholders.
Further study is also recommended to cover similar situation at other school cooperative-mart and the analysis could be extended to verify the cost of dimension between single or multiple servers versus return of investment.

\section{ACKNOWLEDGEMENT}

Ministry of High Education (MOHE), STEM Grant with vote no. A. J091002.5600.07397.

\section{REFERENCES}

Abdul Mukhti Husein. (1997). Pengalaman koperasi sekolah terbaik MRSM Perlis. Kertas Kerja Seminar Hari Koperasi Sekolah. Maktab Kerjasama Malaysia, Petaling Jaya.

Akta Koperasi (1993). Petaling Jaya: Percetakan Maktab Kerjasama Malaysia.

ANGKASA. (1998). Program Pendidikan dan Latihan Koperasi. Petaling Jaya: Penerbit Angkasa.

Barnett, A. I., Saponaro, A. (1985). Misapplication reviews: the parable of the red line, Interfaces, 15, 33- 9.

Crahill, T., Gross, D. B., and Magazine, M. J. (1977). A classified bibliography of research on optimal design and control queues. Operations Research, 25(2), 219-232.

Foote, B. L. (1976). A queuing case study of drive in banking. Interfaces, 6(4), 31- 37 .

Friedman, H. H., Friedman, L. W. (1997). Reducing the-waitll in waiting-line systems: Waiting line segmentation. Business Horizons, 40(4), 54-58.

Gkougkouli, A., S Ris, D. S., Botzoris, G., and Papadopoulos, B. (2014). Fuzzy Performance Measures of M/M/S Queuing Systems using Fuzzy Estimators. Econpapers, XVIII, 3, 17.

Suruhanjaya Koperasi Malaysia. (2016). Retrieved from http://www.skm.gov.my/images/images/Statistik-Gerakan-

Koperasi/Statistik-Tahunan/Buku-Statistik-Gerakan-Koperasi-2016/7-1RINGKASAN-PERANGKAAN-AM-KOPERASI-SEKOLAHMENGIKUT-NEGERI-2016.pdf.

Jones, M. T., O'Berski, A. M., and Gail, T. (1980). Quickening the queue in grocery stores. Interfaces. 10(3), $90-92$.

Kumar, R. and Sharma, S. K. (2014). A Single server markovian queuing systems with discouraged arrivals and retention of reneged customers. Yugoslav Journal of Operations Research, 24(119), 119 - 126.

Lakshmi, C. and Lyer, S. A. (2013). Application of queuing theory in health care. Operations Research for Health Care, 2(1), 25 - 39.

Norazlan, Faisal, M., Samsuddin, J., Arfizawati dan Noranita. (2010). Cabaran Koperasi Pengguna Dalam Aktiviti Peruncitan di Malaysia. Unpublished Thesis. Maktab Kerjasama Malaysia.

Obamiro, J. K. (2010). Queuing Theory and Patient Satisfaction. Bulletin of Petroleum-Gas University of Ploiesti, LXII (1), 1 - 11.

Sahu, C. and Sahu, S. (2014). Implementation of single channel queuing model to enhance banking services. International Journal of Management, Information technology and Engineering, 2, 71 - 78.

Sharma, A. K., Kumar, R., and Sharma, G. K. (2013). Queueing theory approach with queueing model. International Journal of Engineering Science Invention, 2(2), $01-11$.

Smith, W. L. (1999). Work Schedules and Managing Queues. Retrieved on from http://academic.emporia.edu/smithwil/s $99 \mathrm{mg} 4761 \mathrm{~m} 9 . \mathrm{htm}$.

Taylor, S. (1994). Waiting for service: The relationship between delays and evaluations of service. Journal of Marketing, 58(2), 56-69.

Vasumathi, A., and Dhanavanthan, P. (2010). Application of simulation technique in queuing model for ATM facility. International Journal of Applied Engineering Research, Dindigul, 1(3), 469 - 482.

Vinta, E. (1999). Queuing Analysis and Waiting Lines. Retrieved from http://www.luc.edu/faculty/eventa/archive/su483we/quesues.htm

Wang, K., Li, N., and Jiang, Z. (2010). Queuing systems with impatient customers : A review. Service Operations and Logistics and Informatics (SOLI), IEEE International Conference. 15 - 17 July 2010. QingDao, China, China: IEEE, 82 - 67.

Weisselberg, R. C., Coweley, J. G. (1969). Quicken the queue. Journal of Systems Management, 20, 30. 